\title{
ORGAN-SPARING EXCISION OF PEDIATRIC TESTICULAR TERATOMA
}

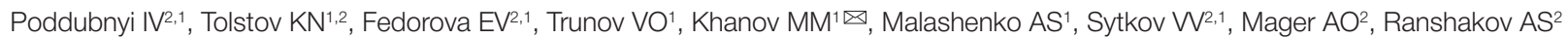

'Federal Scientific and Clinical Center for Children and Adolescents of the FMBA of Russia, Moscow, Russia

${ }^{2}$ A. I. Yevdokimov Moscow State University of Medicine and Dentistry, Moscow, Russia

Pediatric testicular masses are rare pathologies. Many physicians, facing such masses for the first time, have trouble choosing the algorithm of assessment and surgical treatment tactics. Extent of surgery and surgical approach depend directly on preoperative assessment results. The clinical case of the incident testicular mass surgical treatment in a 15-year-old boy is reported. The patient underwent laboratory and instrumental examination, the results of which confirmed a benign lesion. Based on the data obtained, the organ-sparing surgical approach was selected. An assessment algorithm, treatment tactics for testicular mass based on the data obtained, advisability and safety of the organ-sparing treatment approach are reported.

Keywords: organ-sparing surgery, testicular mass, epidermoid cyst, testicular teratoma, urology-andrology, children, pediatrics

Author contribution: Tolstov KN, Khanov MM — concept, manuscript writing; Khanov MM, Tolstov KN, Malashenko AS, Sytkov W, Mager AO, Ranshakov AS data acquisition and processing; Poddubnyi IV, Tolstov KN, Fedorova EV, Trunov VO - manuscript editing; all authors approved the final version of the article.

$\triangle$ Correspondence should be addressed: Mamai M. Khanov

Moskvorechye, 20, Moscow, 115409; 8_00@mail.ru

Received: 10.05.2021 Accepted: 24.05.2021 Published online: 05.06.2021

DOI: $10.47183 /$ mes.2021.010

\section{ОРГАНСБЕРЕГАЮЩЕЕ УДАЛЕНИЕ ТЕРАТОМЫ ЯИЧКА У РЕБЕНКА}

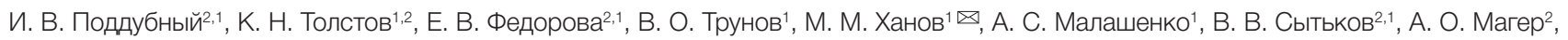
А. С. Раншаков

1 Федеральный научно-клинический центр детей и подростков Федерального медико-биологического агентства России, Москва, Россия

${ }^{2}$ Московский государственный медико-стоматологический университет имени А. И. Евдокимова, Москва, Россия

Образования яичка у детей представляют собой редкую патологию. Нередко у врачей, встречающихся с ней впервые, возникает затруднение в выборе алгоритма обследования и тактики оперативного лечения, объем и методы которого напрямую зависят от результатов предоперационного обследования. Представлен клинический случай хирургического лечения впервые выявленного образования яичка у ребенка 15 лет. Пациенту проведено лабораторно-инструментальное обследование, по результатам которого доказан доброкачественный характер образования. На основании полученных данных выбран органсохраняющий метод оперативного лечения. Представлен алгоритм обследования, тактика лечения образования яичка по результатам полученных данных, целесообразность и безопасность органсберегающего метода лечения.

Ключевые слова: органсохраняющие операции, образование яичка, эпидермальная киста, тератома яичка, урология-андрология, дети, педиатрия

Вклад авторов: К. Н. Толстов, М. М. Ханов - концепция, написание текста; М. М. Ханов, К. Н. Толстов, А. С. Малашенко, В. В. Сытьков, А. О. Магер, А. С. Раншаков - сбор и обработка материала; И. В. Поддубный, К. Н. Толстов, Е. В. Федорова, В. О. Трунов - редактирование; все соавторы утвердили окончательный вариант статьи.

$\triangle$ Для корреспонденции: Мамай Магомедханович Ханов ул. Москворечье, д. 20, г. Москва, 115409; 8_00@mail.ru

Статья получена: 10.05.2021 Статья принята к печати: 24.05.2021 Опубликована онлайн: 05.06.2021

DOI: $10.47183 /$ mes.2021.010

Pediatric testicular masses are rare: their incidence is $0.5-2.0$ cases per 100,000 people [1, 2]. Benign tumors predominate in prepubertal children, who account for about $75 \%$ of cases [2, 3]. Testicular tumors constitute $1 \%$ of all malignant tumors. In $85 \%$ of cases, testicular masses are represented by germ cell tumors [4]. Factors associated with germ cell tumors are as follows: cryptorchidism (risk increased by 5-10 times), infertility (risk increased by 10-20 times), testicular dysgenesis syndrome, germ cell tumor in a first degree relative (risk increased by 5-10 times) [5]. According to international histological classification of testicular germ cell tumors, there are following teratoma types: postpubertal teratoma; teratoma with somatic-type malignancy; prepubertal teratoma; mixed teratoma, prepubertal type [6]. Testicular epidermoid cyst is a form of prepubertal teratoma or mature teratoma, it is a benign germ cell tumor originating from one or more primary germ layers (endoderm, ectoderm and mesoderm). Testicular epidermoid cysts account for $13 \%$ of all pediatric testicular masses. Ultrasonography of the scrotum is considered the imaging modality of choice used for detection of such masses in children. In such cases ultrasonography shows 100\% sensitivity for the detection of the mass, but low specificity for the differentiation of benign and malignant tumors. During the second phase of the assessment, tumor markers and blood biochemistry are analyzed: alpha-fetoprotein (AFP), human chorionic gonadotropin (hCG), lactate dehydrogenase (LDH), and testosterone. In case of equivocal assessment results or signs of malignancy, chest computed tomography (CT) and pelvic magnetic resonance imaging (MRI) are indicated. In the absence of data on malignancy, surgical treatment is indicated. The organ-sparing approach is more and more often described as a priority in literature [3, 7-9].

The paper presents a clinical case of organ-sparing surgery in adolescent boy with benign tumor of the testicle; the algorithm of physician's actions in case of testicular tumor detection is reported.

\section{Clinical case}

Adolescent boy M. aged 15. Physical examination found a hard consistency, elastic, painless mass detected by palpation in the lower pole of the left testicle. The scrotum appeared normal in size; testicle was mobile, of elastic consistency; the mass did not adhere to the surrounding tissue; left testicular veins 


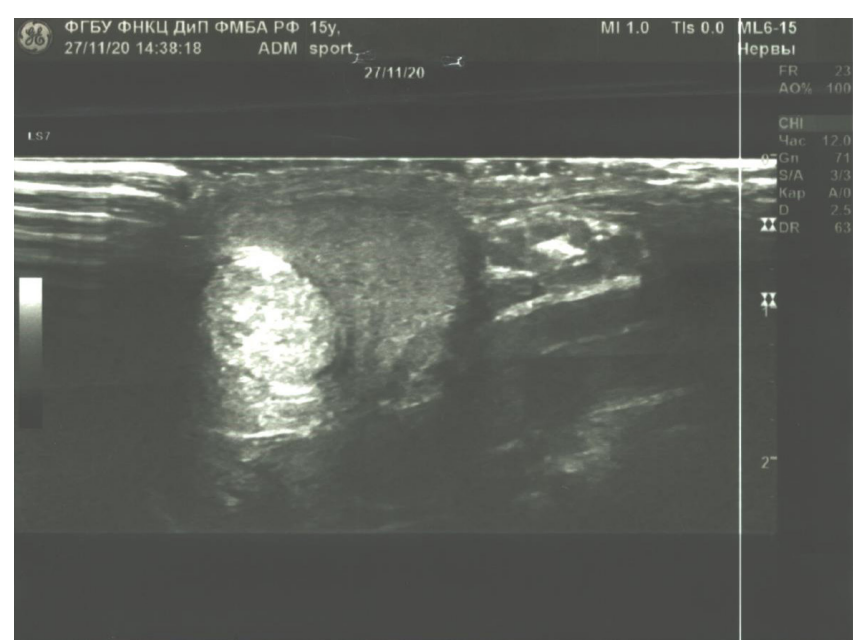

Fig. 1. Ultrasonogram 1. Ultrasound features of avascular lesion of the lower pole of the testis

were not dilated. The patient had no clinical manifestations of the mass, and no history of trauma. The boy was hospitalized in the hospital of the Federal Scientific and Clinical Center for Children and Adolescents of the FMBA of Russia for further assessment and treatment.

\section{Laboratory and instrumental examinations}

The boy underwent scrotal ultrasonography, which revealed a $10.6 \times 9.4 \times 9.2 \mathrm{~mm}$ encapsulated mass of the lower pole of the left testicle with clear, well-defined edges with no signs of spreading into surrounding tissues. Doppler ultrasonography of the mass revealed no detectable blood flow (Fig. 1 and 2).

Blood levels of AFP, b-HCG, LDH, and testosterone were normal.

MRI of pelvic organs and external genitalia was performed due to suspected malignancy (Fig. 3 and 4); no invasion of surrounding tissue or spread to regional lymph nodes and pelvic organs was detected. The $8 \mathrm{~mm}$ mass of the lower pole of the left testicle was revealed, no other pathological features were seen.

The boy got the consultation of oncologist at the N.N. Blokhin National Medical Research Center of Oncology; the testis-sparing excision of the mass was indicated.

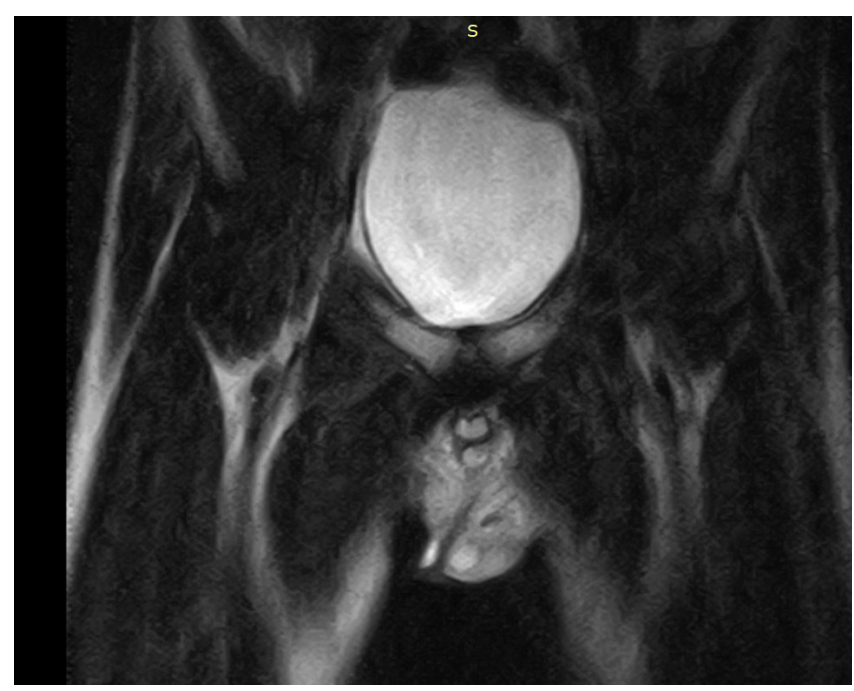

Fig. 3. MRI scan 1. MRI features of left testicular lesion with no signs of tumor spreading to pelvic organs and regional lymph nodes

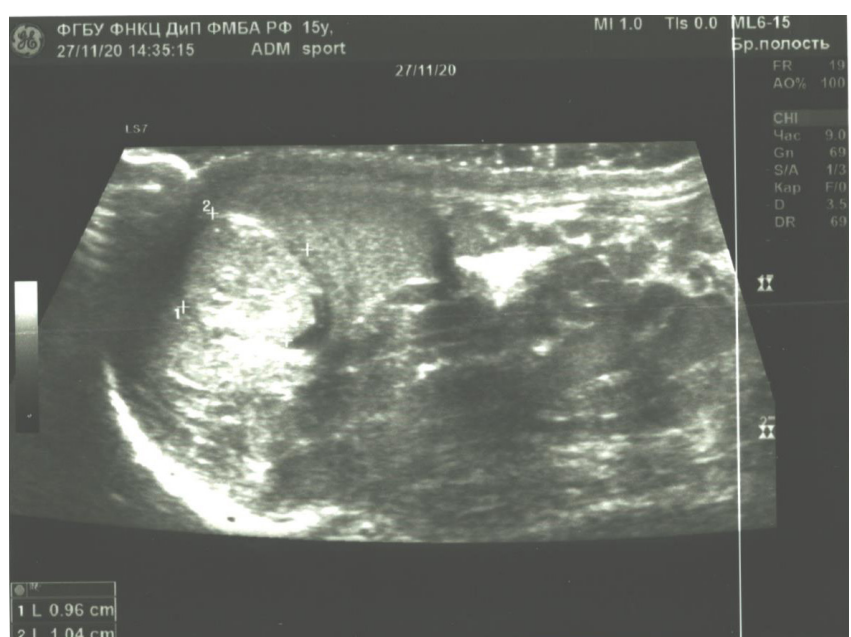

Fig. 2. Ultrasonogram 2. Ultrasound features of avascular lesion of the lower pole of the testis

\section{Surgical treatment}

Dissection of the testicular membranes through trans-scrotal incision was performed with the patient supine under general anesthesia, the small amount of clear exudate was produced. Surgical exploration revealed no changes in testicular tissue. Testicular tissue was dissected in the lower pole, in the projection of the suspected mass. At depth of 5-7 mm the rounded mass with well differentiated capsule slightly adhered to surrounding tissues was seen. Mobilization and excision of the mass were performed step-by-step with blunt/sharp instruments with the use of monopolar coagulation (Fig. 5). The mass was sent for histological examination, testicular membranes and scrotal skin were closed with sutures. Histological examination revealed the epidermoid cyst (prepubertal teratoma).

\section{Post-operative period}

The boy was transferred from the operative room to surgery department for follow-up and planned analgesic therapy. The postoperative period was uneventful, no surgical complications were observed. The follow-up ultrasonography revealed a contents-free residual cavity about $4 \mathrm{~mm}$ in diameter in the projection of the excised mass. The patient was discharged two days after surgery. The follow-up ultrasound examination

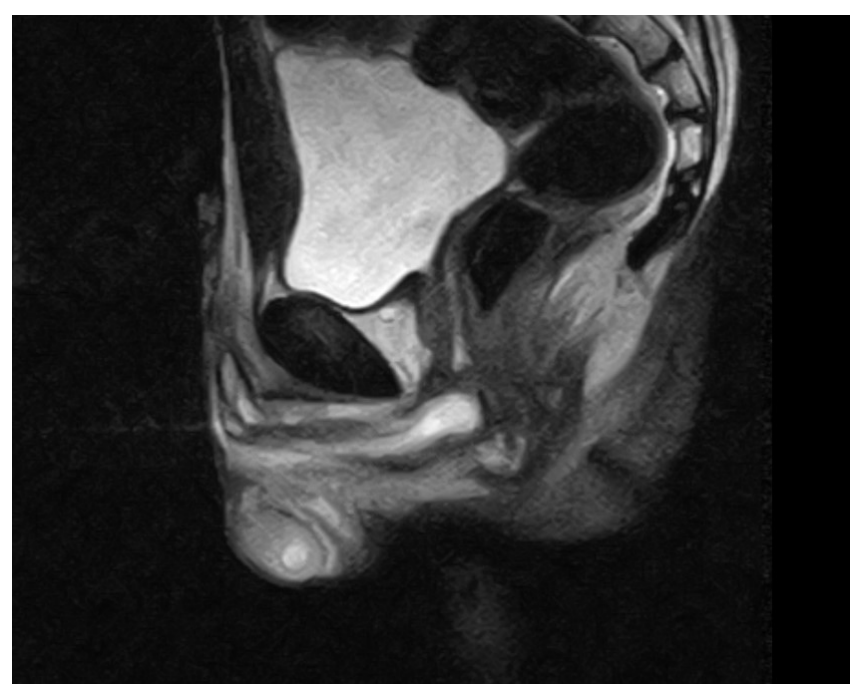

Fig. 4. MRI scan 2. MRI features of left testicular lesion with no signs of tumor spreading to pelvic organs and regional lymph nodes 
of the scrotum every two months was recommended. The scrotal ultrasonography results, obtained 2, 4 and 6 months after surgery, showed no evidence of the tumor recurrence. Ultrasound examination of the scrotum every six months was recommended.

\section{Discussion}

Surgery is a modality of choice for pediatric benign tumors. Concerning the data obtained during the previous years, as well as the experience of "adult" urologists, high inguinal orchifuniculectomy had been performed for a long time due to suspected malignancy, or removal of testicle after testicular biopsy in case of histologically proven benign lesion [10, 11] Taking into account the fact that recent findings demonstrate the predominance of benign neoplasms among testicular tumors, as well as based on the results of 5-year follow-up study in children after enucleation of testicular masses, the organsparing surgery may be considered as a modality of choice for benign testicular tumors [3, 7-9]. The organ-sparing approach is applied when there is no data confirming malignancy, and for small-sized tumors.

Radical inguinal orchofuniculectomy is advisable in cases of proven malignant nature of the mass [10].

\section{Conclusion}

Epidermoid cyst is a benign testicular tumor, usually having no clinical manifestations. Upon detection of testicular mass

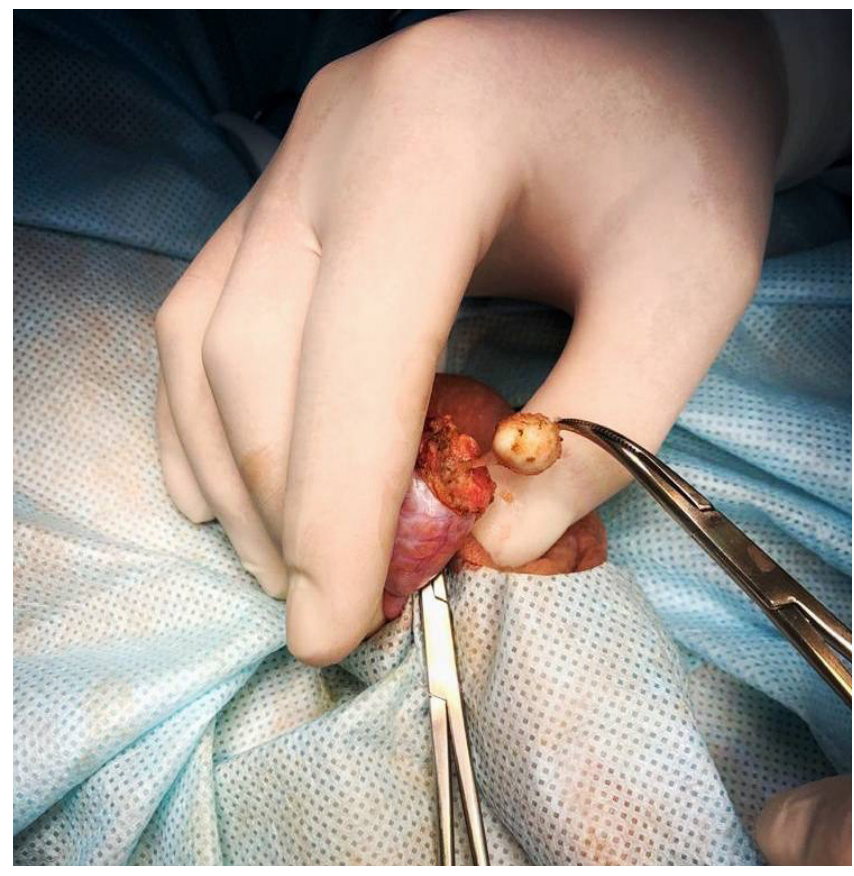

Fig. 5. Intraoperative image. Excision of encapsulated testicular teratoma

and performing a number of diagnostic procedures to confirm a benign lesion, surgical treatment is indicated. Trans-scrotal testis-sparing enucleation of the mass is a modality of choice for benign lesions less than $3 \mathrm{~cm}$ in size.

\section{References}

1. Pohl HG, Shukla AR, Metcalf PD, Cilento BG, Retik AB, Bagli DJ, Huff DS, Rushton HG. Prepubertal testis tumors: actual prevalence rate of histological types. J Urol. 2004 Dec; 172 (6 Pt 1): 2370-2. DOI: 10.1097/01.ju.0000144402.13556.74. PMID: 15538270.

2. Walsh TJ, Grady RW, Porter MP, Lin DW, Weiss NS. Incidence of testicular germ cell cancers in U.S. children: SEER program experience 1973 to 2000. Urology. 2006 Aug; 68 (2): 402-5: discussion 405. DOI: 10.1016/j.urology.2006.02.045. PMID: 16904461

3. Chung JM, Lee SD. Overview of pediatric testicular tumors in Korea. Korean J Urol. 2014 Dec; 55 (12): 789-96. DOl: 10.4111/ kju.2014.55.12.789. Epub 2014 Dec 5. PMID: 25512812; PMCID: PMC4265712.

4. Gill MS, Shah SH, Soomro IN, Kayani N, Hasan SH. Morphological pattern of testicular tumors. J Pak Med Assoc. 2000 Apr; 50 (4): 110-3. PMID: 10851829.

5. Germinogennye opuholi u muzhchin. Klinicheskie rekomendacii. Ministerstvo zdravoohranenija RF, 2020 g. Dostupno po ssylke: https://nop2030.ru/files/2019/08/048.pdf. Russian.

6. Williamson SR, Delahunt B, Magi-Galluzzi C, Algaba F, Egevad L, Ulbright TM, et al. The World Health Organization 2016 classification of testicular germ cell tumours: a review and update

\section{Литература}

1. Pohl HG, Shukla AR, Metcalf PD, Cilento BG, Retik AB, Bagli DJ, Huff DS, Rushton HG. Prepubertal testis tumors: actual prevalence rate of histological types. J Urol. 2004 Dec; 172 (6 Pt 1): 2370-2 DOI: 10.1097/01.ju.0000144402.13556.74. PMID: 15538270.

2. Walsh TJ, Grady RW, Porter MP, Lin DW, Weiss NS. Incidence of testicular germ cell cancers in U.S. children: SEER program experience 1973 to 2000. Urology. 2006 Aug; 68 (2): 402-5; discussion 405. DOI: 10.1016/j.urology.2006.02.045. PMID:

from the International Society of Urological Pathology Testis Consultation Panel. Available from: https://onlinelibrary.wiley. com/doi/abs/10.1111/his.13102.

7. Sangüesa C, Veiga D, Llavador M, Serrano A. Testicular tumours in children: an approach to diagnosis and management with pathologic correlation. Insights Imaging. 2020; 11 (1): 74. Published 2020 May 27. DOI: 10.1186/s13244-020-00867-6.

8. Romo Muñoz MI, Núñez Cerezo V, Dore Reyes M, Vilanova Sánchez A, González-Peramato P, López Pereira P, et al. Tumores testiculares en la edad pediátrica: indicaciones de la cirugía conservadora Testicular tumours in children: Indications for testis-sparing surgery]. An Pediatr (Barc). 2018 May; 88 (5): 253-8. DOI: 10.1016/j.anpedi.2017.05.009. Epub 2017 Jul 17. PMID: 28729185. Spanish.

9. Kooij CD, Hulsker CCC, Kranendonk MEG, et al. Testis Sparing Surgery in Pediatric Testicular Tumors. Cancers (Basel). 2020; 12 (10): 2867. Published 2020 Oct 6. DOI: 10.3390/ cancers12102867.

10. Rohoev M. A. Opuholi jaichka i paratestikuljarnye opuholi u detej. Diagnostika, lechenie [dissertacija]. M., 2014. Russian.

11. Brosman SA. Testicular tumors in prepubertal children. Urology. 1979; 13 (6): 581-8.

16904461

3. Chung JM, Lee SD. Overview of pediatric testicular tumors in Korea. Korean J Urol. 2014 Dec; 55 (12): 789-96. DOI: 10.4111/ kju.2014.55.12.789. Epub 2014 Dec 5. PMID: 25512812; PMCID: PMC4265712.

4. Gill MS, Shah SH, Soomro IN, Kayani N, Hasan SH. Morphological pattern of testicular tumors. J Pak Med Assoc. 2000 Apr; 50 (4): 110-3. PMID: 10851829. 
5. Герминогенные опухоли у мужчин. Клинические рекомендации. Министерство здравоохранения РФ, 2020 г. Доступно по ссылке: https://nop2030.ru/files/2019/08/048.pdf.

6. Williamson SR, Delahunt B, Magi-Galluzzi C, Algaba F, Egevad L, Ulbright TM, et al. The World Health Organization 2016 classification of testicular germ cell tumours: a review and update from the International Society of Urological Pathology Testis Consultation Panel. Available from: https://onlinelibrary.wiley. com/doi/abs/10.1111/his.13102.

7. Sangüesa C, Veiga D, Llavador M, Serrano A. Testicular tumours in children: an approach to diagnosis and management with pathologic correlation. Insights Imaging. 2020; 11 (1): 74 Published 2020 May 27. DOl: 10.1186/s13244-020-00867-6.

8. Romo Muñoz MI, Núñez Cerezo V, Dore Reyes M, Vilanova
Sánchez A, González-Peramato P, López Pereira $\mathrm{P}$, et al. Tumores testiculares en la edad pediátrica: indicaciones de la cirugía conservadora [Testicular tumours in children: Indications for testis-sparing surgery]. An Pediatr (Barc). 2018 May; 88 (5): 253-8. DOl: 10.1016/j.anpedi.2017.05.009. Epub 2017 Jul 17. PMID: 28729185. Spanish.

9. Kooij CD, Hulsker CCC, Kranendonk MEG, et al. Testis Sparing Surgery in Pediatric Testicular Tumors. Cancers (Basel). 2020; 12 (10): 2867. Published 2020 Oct 6. DOI: 10.3390/ cancers12102867.

10. Рохоев М. А. Опухоли яичка и паратестикулярные опухоли у детей. Диагностика, лечение [диссертация]. М., 2014.

11. Brosman SA. Testicular tumors in prepubertal children. Urology. 1979; 13 (6): 581-8. 